\title{
Idiopathic Tall Stature
}

National Cancer Institute

\section{Source}

National Cancer Institute. Idiopathic Tall Stature. NCI Thesaurus. Code C118692.

Tall stature for which no underlying cause can be found. 